\title{
Basic Characteristics of Three-phase Variable Inductor
}

\author{
K. Nakamura, S. Hisada, T. Ohinata*, K. Arimatsu*, Y. Sato*, and O. Ichinokura \\ Graduate School of Engineering, Tohoku University, 6-6-05 Aoba, Aramaki, Aoba-ku, Sendai 980-8579, Japan \\ *Tohoku Electric Power Co., Inc., 7-2-1 Nakayama, Aoba-ku, Sendai 981-0952, Japan
}

A variable inductor consists of magnetic cores and primary and secondary windings. It can regulate the effective inductance of the secondary winding by dc excitation from the primary winding. Variable inductors are expected to be applied to reactive power compensation in electric power systems, because they have a simple robust structure that is extremely reliable. This paper proposes a novel three-phase variable inductor to reduce size and weight. First, the operating principles of the proposed variable inductor are explained. Next, basic characteristics of the proposed variable inductor we calculated by reluctance network analysis (RNA) and the finite element method (FEM) are presented, which we compare with those of a conventional EIE-core variable inductor.

Key words: three-phase variable inductor, reluctance network analysis (RNA), finite element method (FEM)

\section{3 相一体構造可変インダクタの基礎特性}

中村健二，久田周平，大日向敬*，有松健司*，佐藤佳彦*，一八倉理

東北大学 大学院工学研究科, 仙台市青葉区荒巻字青葉 6-6-05（干980-8579）

*東北電力(株) 研究開発センター，仙台市青葉区中山 7-2-1（†981-0952）

\section{1. はじめに}

近年，負荷の増大と多様化，ならびに太陽光や風力などの分散 型電源の導入により, 系統の電圧が不規則かつ急峻に変動する問 題が顕在化している. 従来, 系統の電圧調整は負荷時タップ切換 変圧器や, SVR（Step Voltage Regulator）など，主として機械式 接点を有する機器により行われてきた。しかしながら，これらの 機器では制御がステップ状になり，またタップ切り換えに時間遅 れが生じる. 従って，不規則かつ急峻な電圧変動を抑制するため には, 従来機器だけでの対応は困難であり, 高速かつ連続制御が 可能で, 安価で信頼性の高い電圧調整機器の開発が望まれる.

最近では，電力用半導体素子を用いた SVC（Static Var Compensator) やSVG (Static Var Generator) など，いわゆる FACTS (Flexible AC Transmission System) 機器も提案されて いる1)-3). しかしながら，これらの機器では，主回路に半導体素子 が用いられるため, 信頼性が特に重要視される我が国の電力系統 には，必ずしも適さないと考えられる．また，大電力を高速にス イッチングした際に生じる, 電磁ノイズの問題も指摘されている.

これに対し，制御側からの直流励磁によって交流主巻線の実効 的なインダクタンスを任意に調整できる可変インダクタは，これ を電力用コンデンサと組み合わせて線路に並列に接続することで, 無効電力補償型の電圧調整機器として応用できる. 可変インダク 夕は，変圧器などと同じ銅鉄機器であるため，構造が極めて簡単 で堅牢，サージ電圧や過電流に対する而性が高いなど，信頼性が 特に重要視される我が国の電力系統に適した特長を有している.

筆者らは，これまで直交磁心や積層平行磁心など種々の可変イ ンダクタの開発を進めるとともに，高圧配電系統への適用技術に 関する検討を進めてきた ${ }^{4)-6)}$. この中で田形磁心は, 積み鉄心で構 成可能であるため大容量化が容易であること，ギャップレスで出 力電流歪みが小さいことなど, 電力用可変インダクタとして望ま しい特長を有している7). また，応答速度も 60～80 ms 以内と実 用上十分な速さを達成している.
一方，可変インダクタは銅鉄機器であることから，一般に大容 量化に伴い重量が増大寸る傾向にある. 特に電力系統への応用を 考えた場合, 可変インダクタは 3 相構成とする必要があるため, 小型・軽量化は実用化に向けた重要な課題である. ここで, 系統 用変圧器については小型・軽量化のため, 3 脚鉄心を用いた 3 相一 体構造が広く一般に知られているが，可変インダクタについては， これまで単相構造しか考案されておらず, 3 相一体構造の可変イン ダクタの開発が強く望まれる.

本稿では, 新しい 3 相一体構造可変インダクタを提案するとと もに, リラクタンスネットワーク解析 (RNA) と有限要素法 (FEM) を用いて基礎特性の算定を行った。 また，従来の田形磁心を用い た可変インダクタとの比較により, どの程度の軽量化が実現でき るか評価したので報告する.

\section{3 相一体構造可変インダクタの基本構成と動作原理}

Fig. 1 に, 本稿で提案する 3 相一体構造可変インダクタの基本構 成を示寸. 本可変インダクタは, 6 つの脚と継鉄, ならびに 6 つの 直流制御巻線と交流主巻線で構成される. 同一線上の 2 つの脚に は，それぞれ同一相の交流主巻線 $N_{u}, N_{v}, N_{w}$ が図の矢印の方向

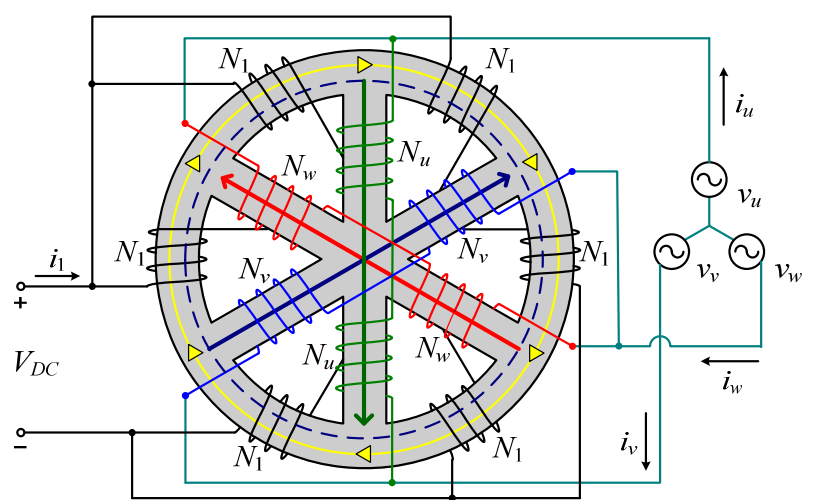

Fig. 1 Basic configuration of proposed three-phase variable inductor. 
に主磁束が流れるように施され，3相デルタ結線される. 向かい合 う 2 つ継鉄には，それぞれ直流制御巻線 $N_{1}$ が施され，交流磁束 による誘起電圧を打ち消すように直列接続される. さらに，これ ら3 組の制御巻線は並列に結線され, 直流電源 $V_{D C}$ に接続される.

Fig. 2 に示寸簡易磁気回路を用いて, 3 相一体構造可変インダク 夕の動作を考察する. 図中の $R_{m}$ と $R_{m}^{\prime}$ は各磁路の磁気抵抗である. いま, 磁気抵抗 $R_{m}$ における起磁力 $F$ と磁束 $\phi$ の関係を, 磁気飽和 を考慮して，次のような磁束のべき級数で表す.

$$
F(\phi)=a_{1} \phi+a_{3} \phi^{3}+a_{5} \phi^{5}+\cdots
$$

ここで， $a_{1}, a_{3}, a_{5}, \cdots$ は係数である. 一方，磁気抵抗 $R_{m}^{\prime}$ における起磁力 $F^{\prime}$ と磁束 $\phi$ の関係は, Fig. 1 に示した主巻線と制 御巻線が施されている磁路の比が $1: \pi / 3$ であることから,

$$
\begin{aligned}
F^{\prime}(\phi) & =\frac{\pi}{3}\left(a_{1} \phi+a_{3} \phi^{3}+a_{5} \phi^{5}+\cdots\right) \\
& =\frac{\pi}{3} F(\phi)
\end{aligned}
$$

で表すことができる．以下，本稿では簡単のため， 式の次数は 3 次まで考慮する.

(1), (2)式を用いて，Fig. 2 の簡易磁気回路から巻線電流 による起磁力 $N_{1} i_{1}, N_{u} i_{u}$ と磁束の関係を求めると, 次式が 得られる。

$$
\begin{aligned}
N_{1} i_{1}= & {\left[\frac{2}{3} \pi a_{1}+\frac{\pi}{6} a_{3}\left\{3\left(\phi_{u}^{2}+\phi_{v}^{2}+\phi_{w}^{2}\right)\right.\right.} \\
& \left.\left.-2\left(\phi_{u} \phi_{v}+\phi_{v} \phi_{w}+\phi_{w} \phi_{u}\right)\right\}+\frac{2}{3} \pi a_{3} \phi_{1}^{2}\right] \phi_{1} \\
N_{u} i_{u}= & \left\{2 a_{1}\left(1+\frac{\pi}{3}\right)+2 \pi a_{3} \phi_{1}^{2}+\left(2+\frac{\pi}{4}\right) a_{3} \phi_{u}^{2}\right. \\
& \left.+\frac{\pi}{12} a_{3}\left(5 \phi_{v}^{2}-2 \phi_{v} \phi_{w}+5 \phi_{w}^{2}\right)\right\} \phi_{u}
\end{aligned}
$$

(4)式において $N i=R_{m} \cdot \phi$ より, 2 次巻線から見た磁気抵抗 $R_{m u}$ は，次式で表される.

$$
\begin{aligned}
R_{m u} & =2 a_{1}\left(1+\frac{\pi}{3}\right)+2 \pi a_{3} \phi_{1}^{2}+\left(2+\frac{\pi}{4}\right) a_{3} \phi_{u}^{2} \\
& +\frac{\pi}{12} a_{3}\left(5 \phi_{v}^{2}-2 \phi_{v} \phi_{w}+5 \phi_{w}^{2}\right)
\end{aligned}
$$

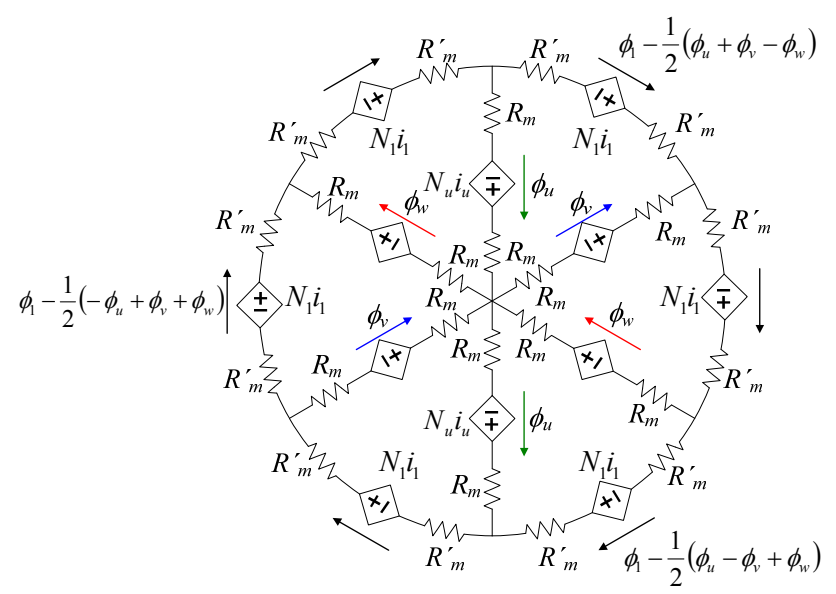

Fig. 2 Simple magnetic circuit of three-phase core.
ここで，主巻線のインダクタンスは $L_{u}=N_{u}^{2} / R_{m u}$ であることから， 制御磁束と主磁束の双方の関数になっていることがわかる. すな わち, 主巻線の実効的なインダクタンスが制御電流によって制御 される, 可変インダクタとして動作することが了解される.

\section{RNA および FEM による基礎特性の算定}

\subsection{3 相一体構造磁心の RNA モデルおよび FEM モデル}

Fig. 3 に，本稿での考察に用いた 3 相一体構造磁心の形状と寸 法を示す. Table 1 は諸元である. 本可変インダクタの解析には, RNAおよびFEMを用いた。

RNA は解析対象を複数の要素に分割し, これらを磁気抵抗に置 き換えることで，対象全体を 1 つ磁気抵抗回路網として計算す る手法である. 磁心形状や非線形磁気特性の考慮が可能，解析モ デルが簡便で計算が速く算定精度が高い，電気系，熱系，運動系 との連成解析が容易, 汎用の回路シミュレータをソルバとして利 用可能など, RNAは電気機器の解析・設計に適した特長を多数有

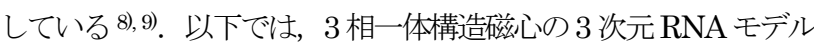
の導出方法について述べる ${ }^{10)}$ ．なお，導出するモデルは磁界の対 称性に基づき，積層方向に対して $1 / 2$ モデルとする.

まず，3 相一体構造磁心を形状および磁束の流れを勘案して, Fig. 4(a)に示すように複数の要素に分割する. このとき磁心からの 漏れ磁束も考慮できるように, 磁心外空間も解析領域に含める. 分割した各々の要素は, 同図(b)に示すような 3 次元方向の 6 つの 磁気抵抗に置き換える. これらの磁気抵抗は, 磁心部のものであ れば, 要素の寸法と材料の $B-H$ 曲線で決まる非線形磁気抵抗とし, 空間部のものであれば, 要素の寸法と真空の透磁率で決まる線形 の磁気抵抗とする.

本稿では, Fig. 5(a)に示すように, 解析領域を磁心外空間 1 層ま でとしたモデルと, 同図(b)のように 2 層まで広げたモデルを導出 した.

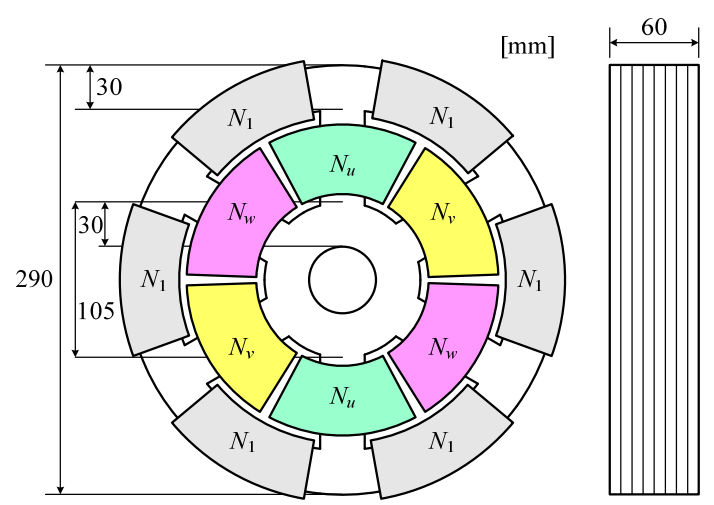

Fig. 3 Schematic of three-phase-core.

Table 1 Specifications for three-phase core.

\begin{tabular}{|c|l|}
\hline$N_{1}$ & $\begin{array}{l}114 \text { turns } \times 6 \\
0.762 \Omega\end{array}$ \\
\hline$N_{u}, N_{v}, N_{w}$ & $\begin{array}{l}208 \text { turns } \times 2 \\
0.906 \Omega\end{array}$ \\
\hline Voltage & $200 \mathrm{~V}$ \\
\hline Rated capacity & $4 \mathrm{kVA}$ \\
\hline Control current & DC 0 to $10 \mathrm{~A}$ \\
\hline Core material & Non-oriented silicon steel \\
\hline
\end{tabular}




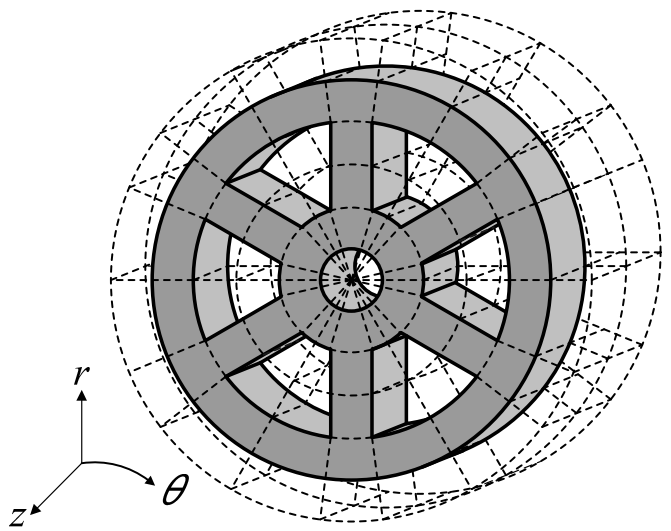

(a) Division of three-phase core based on RNA.

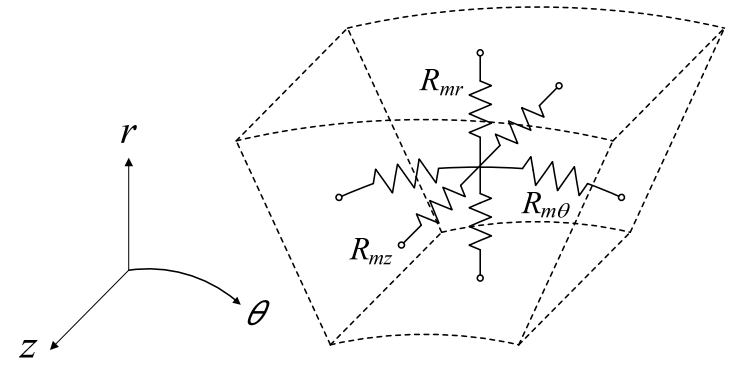

(b) Three-dimensional unit magnetic circuit.

Fig. 4 Three-dimensional RNA model of three-phase core.
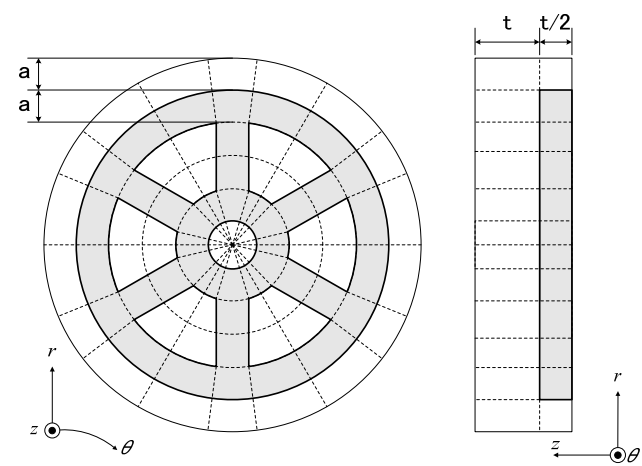

(a) One layer
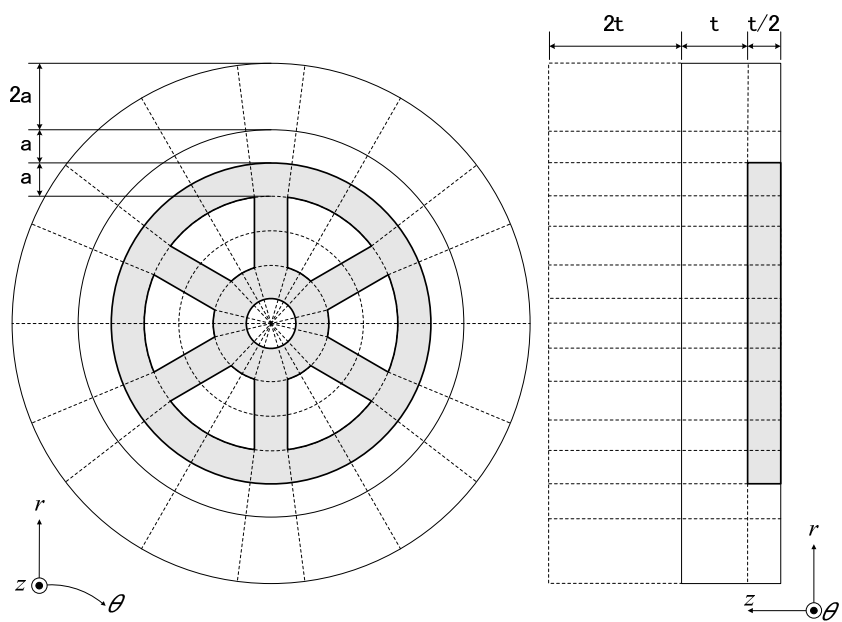

(b) Two layers

Fig. 5 Analytical domains of RNA model of three-phase core.
Fig. 6 には, 3 相一体構造磁心の3 次元FEMモデルを示す. FEM モデルにおいても RNA モデルと同様に, 磁界の対称性を考慮して, 積層方向に対して $1 / 2$ モデルを作成した. また, 磁心寸法の 5 倍 に当たる磁心外空間までを解析領域に含めた. 要素数は 134,232 である.

\section{2 特性算定結果}

Fig. 7 に, 3 相一体構造可変インダクタの無効電力制御特性を示 す. 図の破線は RNA において磁心外空間を 1 層とした場合の計 算值であり，実線は 2 層とした場合の計算值である.また，シン ボルは FEM による計算值である. この図を見ると, 提案する可 変インダクタは, 無効電力を連続かつ線形に制御可能であること がわかる。

Fig. 8 に, 定格換算した出力電流の歪み率を示す。ここで歪み 率とは, 可変インダクタにおいて高調波の主成分となる第 5 調波, 第 7 調波の基本波に対する割合である. なお, 3 の倍数の高調波は 主巻線をデルタ結線して還流させているため, 出力電流には現れ ない. この図より, 解析領域を磁心外空間 1 層とした RNA の計 算值と FEM の計算值には差異が認められるが, 2 層まで広げると RNA と FEM の結果はほぼ一致することがわかる. また, 歪み率 は全制御範囲で $4 \%$ 以下であることがわかる. Fig. 9 は直流制御電 流を $10 \mathrm{~A}$ とした場合の交流側の出力電流波形である. この図を見 ると，電流波形はほぼ正弦波であることがわかる.

以上の結果より, 提案寸る 3 相一体構造可変インダクタが良好 な制御性と低電流歪み特性を有することが示された。

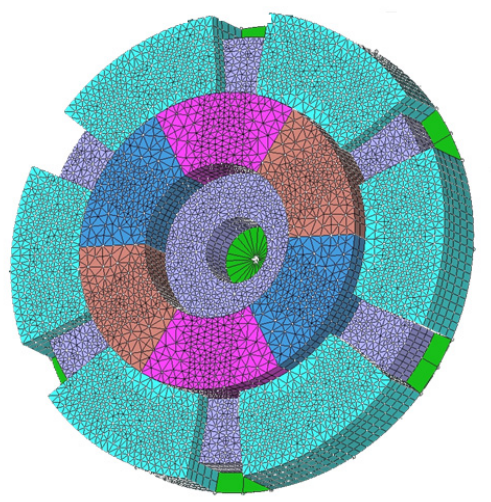

Fig. 6 3D FEM model of three-phase-core.

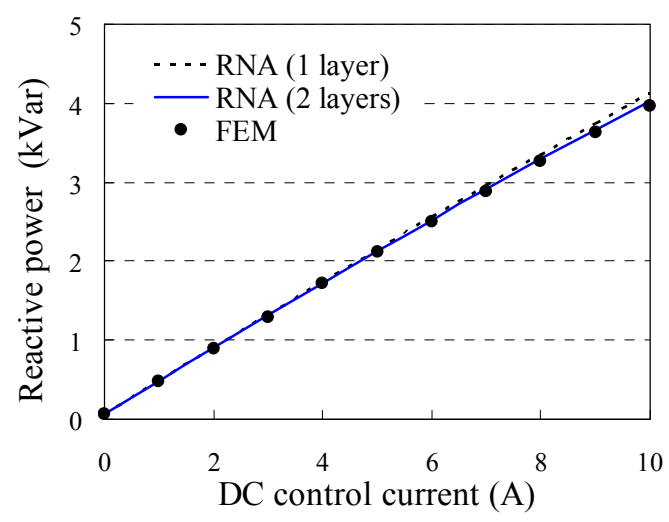

Fig. 7 Control characteristics of reactive power. 


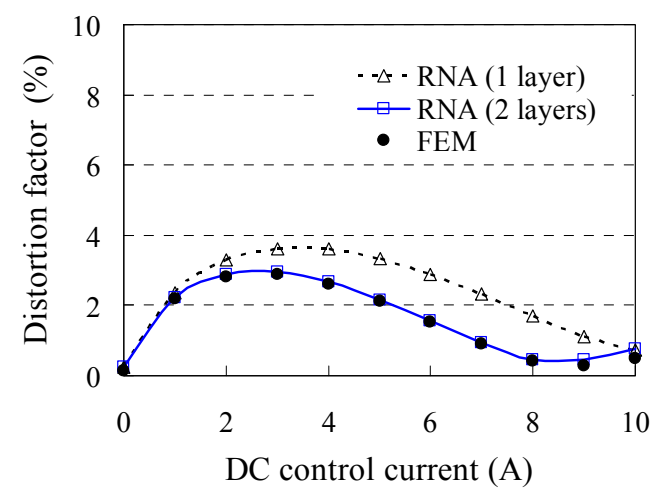

Fig. 8 Distortion factor of output current.

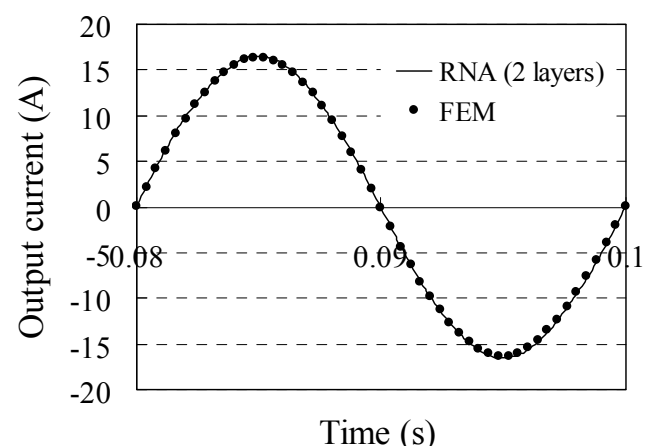

Fig. 9 Waveforms of output current when dc control current is $10 \mathrm{~A}$.

\section{4. 田形磁心による可変インダクタとの比較および検討}

Fig. 10 に，比較に用いた田形磁心の形状と寸法を示寸8). Table 2 は磁心の諸元である. 磁心材質は，3相一体構造磁心と同じ無方 向性ケイ素鋼板である，また，巻線の占積率ならびに動作磁束密 度も 3 相一体構造磁心と等しい，田形磁心の鉄心と巻線を合わせ た重量は概算で $13.1 \mathrm{~kg}$ であるが，単相器であるため，3相の可変 インダクタとして用いる場合の重量は $39.3 \mathrm{~kg}$ になる. 一方, Fig. 3 に示した 3 相一体構造磁心の鉄心と巻線を合わせた重量は 33.4 kgである.

Fig. 11 に, RNA で求めた 3 相一体構造磁心と田形磁心の単位 重量当りの無効電力制御特性を示寸。この図を見ると，同一主巻 線電流密度における無効電力は，3相一体構造磁心の方が 30 \%以 上優れていることがわかる. 寸なわち，同一制御量であれば 3 相 一体構造磁心の方が， 30 \%以上軽量化できることを意味する.

\section{5. まとめ}

以上，本稿では新しい 3 相一体構造可変インダクタを提案し， 動作原理について考察するとともに，RNAおよびFEM を用いて 諸特性の算定を行った.

その結果，提案した 3 相一体構造可変インダク夕は，良好な制 御特性と低電流歪み特性を有することが示された．また，田形磁 心との比較により，30\%以上の軽量化が実現できる可能性が示さ れた. 今後は実機の製作と検証実験を行う予定である.

なお，本研究の一部は科学研究費補助金若手研究(B)(19760188), ならびに(財)カシオ科学振興財団の交付を得て行った.

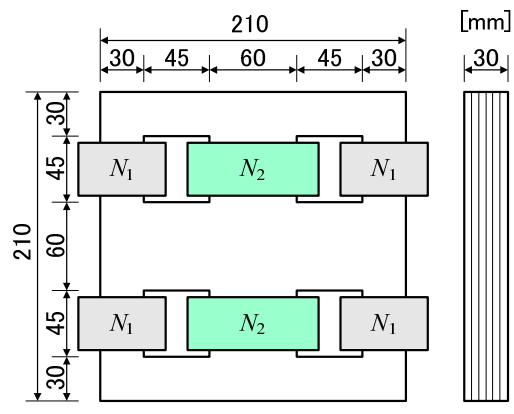

Fig. 10 Schematic of EIE-core.

Table 2 Specifications for EIE-core.

\begin{tabular}{|c|l|}
\hline$N_{1}$ & $\begin{array}{l}100 \text { turns } \times 4 \\
0.442 \Omega\end{array}$ \\
\hline$N_{2}$ & $\begin{array}{l}156 \text { turns } \times 2 \\
0.68 \Omega\end{array}$ \\
\hline Voltage & $150 \mathrm{~V}$ \\
\hline Rated capacity & $1.2 \mathrm{kVA}$ \\
\hline Control current & DC 0 to $10 \mathrm{~A}$ \\
\hline Core material & Non-oriented silicon steel \\
\hline
\end{tabular}

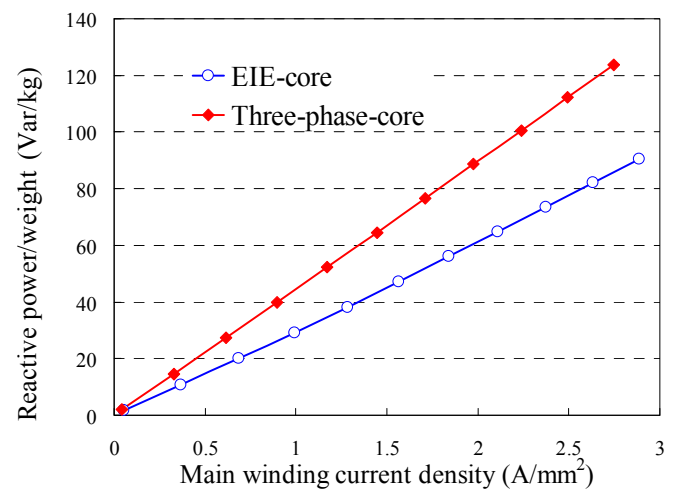

Fig. 11 Comparison of controlled reactive power per weight for three-phase and EIE-core variable inductors.

\section{References}

1) T. Hayashi and T. Sakurai, T. IEE Jpn., 117-B, 901 (1997) (in Japanese).

2) S. Irokawa, T. IEE Jpn, 115-B, 1019 (1995) (in Japanese)

3) F. Ichikawa, T. IEE Jpn, 112-B, 461 (1992) (in Japanese).

4) M. Maeda, S. Akatsuka, T. Ito, and O. Ichinokura, J. Magn. Soc. Jpn., 23, 1787 (1999) (in Japanese).

5) K. Nakamura, S. Akatsuka, T. Ohinata, M. Kawakami, M. Maeda, H. Sato, and O. Ichinokura, T. IEE Jpn., 122-B, 295 (2002) (in Japanese).

6) O. Ichinokura, K. Nakamura, S. Akatsuka, T. Ohinata, and K. Minazawa, Trans. Magn. Soc. Jpn., 5, 49 (2005).

7) M. Maeda, T. Ohinata, T. Aoki, S. Akatsuka, M. Kawakami, H. Sato, and O. Ichinokura, T. IEE Jpn., 122-B, 561 (2002) (in Japanese).

8) S. Hayakawa, K. Nakamura, S. Akatsuka, T. Aoki, M. Kawakami, T. Ohinata, K. Minazawa, and O. Ichinokura, $J$. Magn. Soc. Jpn., 28, 425 (2004) (in Japanese).

9) K. Nakamura and O. Ichinokura, T. IEE Jpn., 126-B, 150 (2006) (in Japanese).

10) K. Nakamura, S. Hisada, K. Arimatsu, T. Ohinata, Y. Sato, and O. Ichinokura, The paper of technical meeting on Magnetics, IEE Jpn., MAG-07-22 (2007) (in Japanese).

2007年09月26日受理，2008年02月14日採録 